\title{
Dystrophic Intracranial Calcification Accompanying Varix of the Dural Sinus and Arteriovenous Malformation
}

\author{
Dural Sinüs Varisi ve Arteriyovenöz Malformasyona Eşlik Eden Distrofik \\ Intrakraniyal Kalsifikasyon
}

\author{
(1) Mehmet Haydar Atalar ${ }^{1}$, (1) Rıfat Nuri Şener², (1) Bülent Yıldız , (1) Özlem Kayım Yıldız \\ ${ }^{1}$ Cumhuriyet University Faculty of Medicine, Department of Radiology, Sivas, Turkey \\ ${ }^{2}$ Ege University Faculty of Medicine, Department of Radiology, Izmir, Turkey \\ ${ }^{3}$ Cumhuriyet University Faculty of Medicine, Department of Neurology, Sivas, Turkey
}

Keywords: Arteriovenous malformation, intracranial calcification, imaging

Anahtar Kelimeler: Arteriyovenöz malformasyon, intrakraniyal kalsifikasyon, görüntüleme

\section{Dear Editor,}

Intracranial calcifications may occur for various reasons and manifest with a variety of symptoms and signs. They are commonly encountered in neuroradiology daily practice. The main causes of calcification include hypoparathyroidism, pseudohypoparathyroidism, Fahr disease, Wilson disease, mitochondrial encephalopathies, neoplasms, anoxia, carbon monoxide and lead poisoning, and radiotherapy. They may also rarely develop secondary to an underlying vascular pathology, as in our patient $(1,2,3)$. A 15-year-old boy was admitted to the emergency service following a generalised tonic-clonic seizure. No specific neurologic deficit was detected in a physical examination. Routine hematology, liver function tests, renal and thyroid function tests, and serum calcium and phosphorus levels were all normal. An urgent computed tomography (CT) scan was performed. A CT of the brain showed extensive gyriform calcifications located at the corticomedullary junction (Figure 1A, 1B). There was a calcified varix $(\mathrm{V})$ connected with the superior sagittal sinus. For a detailed view of the detected findings in CT, magnetic resonance (MR) imaging and MR angiography (MRA) were performed. MR examinations showed dilated middle cerebral, and posterior cerebral arteries also supplying the arteriovenous malformation. T2-weighted and post-contrast T1weighted MR images showed the V, as well as MRA (Figure 1C). Conventional angiography demonstrated a nidus of a parenchymal arteriovenous malformation. In addition, the cerebellum was abnormal; there was herniation of the cerebellar tonsils into the cervical canal, and the superior vermis showed towering such as that seen in Chiari 2 malformation (Figure 1D). Arteriovenous malformation is a rare albeit clinically important condition. Calcification due to intracranial arteriovenous malformation is not uncommon. These calcifications have an identical pattern to the so-called mineralizing microangiopathy, which is known to be associated with vasculopathy and dystrophic calcification at the corticomedullary junction, and the basal ganglia, and usually develops after combined chemotherapy and radiation treatment of the central nervous system tumors in childhood. Although the mechanism underlying calcifications associated with vascular anomalies is not entirely clear, calcifications accompanying arteriovenous malformations are considered to be related to arterial steal phenomenon in chronically hypoperfused brain parenchyma or occluded vessel walls, or to a dystrophic process that develop as a result of resistant venous congestion. Cerebral corticomedullary subcortical white matter regions are found in the arterial basins and thus more sensitive to hypoxic-ischemic changes $(1,2,3,4,5)$. The calcifications in our patient may have resulted from a longstanding vasculopathy. In conclusion, intracranial calcifications may be clinically nonsignificant but may also manifest as a critical sign of a serious underlying condition. The differential diagnosis of corticomedullary, subcortically-located intracranial calcifications detected by cross-sectional imaging techniques should definitely include intracranial vascular anomalies.

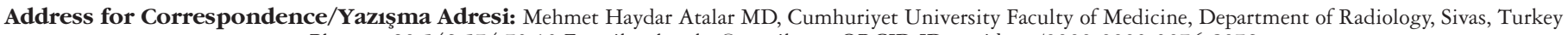
Phone: +90 5425747313 E-mail: mhatalar@gmail.com ORCID ID: orcid.org/0000-0003-3076-8072

Received/Geliş Tarihi: 08.02.2018 Accepted/Kabul Tarihi: 30.03 .2018

${ }^{\circ}$ Copyright 2018 by Turkish Neurological Society

Turkish Journal of Neurology published by Galenos Publishing House. 


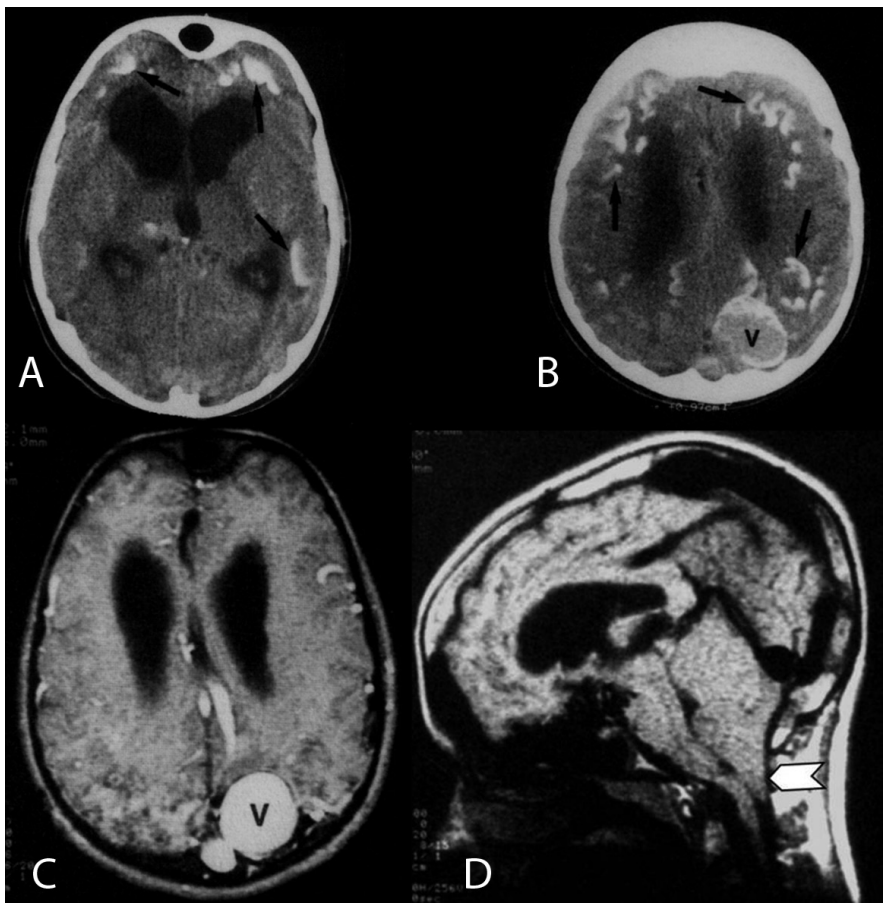

Figure 1. A, B) Axial unenhanced computed tomography images demonstrate extensive gyriform calcifications (arrows) located at the corticomedullary junction and a calcified varix connected with the superior sagittal sinus, C) Post-contrast axial T1-weighted magnetic resonance image shows the varix, D) sagital T1-weighted magnetic resonance image demonstrates herniation of cerebellar tonsils into the cervical canal (arrowhead), and the superior vermis showed towering.

\section{Ethics}

Informed Consent: Not needed.

Peer-review: Internally peer-reviewed.

\section{Authorship Contributions}

Surgical and Medical Practices: M.H.A., R.N.Ş., Concept: M.H.A, B.Y., Ö.K.Y., Design: M.H.A., Data Collection or Processing: R.N.Ş., Analysis or interpretation: M.H.A., Literature Search: M.H.A., R.N.Ş., B.Y., Writing: M.H.A., Ö.K.Y.

Conflict of Interest: No conflict of interest was declared by the authors.

Financial Disclosure: The authors declared that this study received no financial support.

\section{References}

1. Sato Y. Basal ganglia calcifications in childhood. Semin Pediatr Neurol 2003;10:96-102.

2. Chen Z, Feng H, Zhu G, Wu N, Lin J. Anomalous Intracranial Venous Drainage Associated with Basal Ganglia Calcification. AJNR Am J Neuroradiol 2007;28:22-24.

3. Yang MS, Chen CC, Cheng YY, Yeh DM, Lee SK, Tyan YS. Unilateral subcortical calcification: a manifestation of dural arteriovenous fistula. AJNR Am J Neuroradiol 2005;26:1149-1151.

4. Kıroğlu Y, Callı C, Karabulut N, Oncel C. Intracranial calcifications on CT. Diagn Interv Radiol 2010;16:263-269.

5. Yu YL, Chiu EK, Woo E, et al. Dystrophic intracranial calcification: CT evidence of 'cerebral steal' from arteriovenous malformation. Neuroradiology 1987;29:519-522. 